IP Periodica Polytechnica Civil Engineering

\author{
60(1), pp. 6173 2016 \\ DOI: $10.3311 /$ PPci.7752 \\ Creative Commons Attribution (1) \\ RESEARCH ARTICLE
}

\section{Geotechnical Analysis of Hill's Slopes Areas in Heritage Town of Berati, Albania}

\author{
Ylber Muceku, Oltion Korini, Alban Kuriqi
}

Received 13-10-2014, revised 29-06-2015, accepted 30-06-2015

\begin{abstract}
In this paper are treated briefly the geotechnical analysis of hills slopes areas in the heritage town of Berati, Albania. From engineering geological mapping on scale 1:10 000 and geotechnical investigations carried out in urban area of Berati town was found that two zones are threated from landslides phenomenon. The first one is located in center part, whereas the second in northeast part of Berati urban area. Mass movements occurred in the studied area are present in rocks topple, rocks fall and earth slide types. Rock falls and topple occur on steep slopes of fractured lime-stone rock, whereas the earth slides are found on medium-steep slopes that are built from soils and weathered fysch rocks. From mass movements occurrences many buildings and urban roads are demolished, thus endangering human life. In these conditions a detailed engineering geological study was undertaken to determine landslide distributions and recognize the stable and unstable areas. Also, based on these studies suggestions and recommendations are given for urban development and remedial measures.
\end{abstract}

\section{Keywords}

Rocks topple $\cdot$ rocks fall $\cdot$ earth slides $\cdot$ and slope stability · stable and unstable areas

\footnotetext{
YIber Muceku

Institute of Geosciences, Energy, Water and Environment, Polytechnic University of Tirana, Don Bosko nr.60, 1024, Tirana, Albania

e-mail: y.muceku@geo.edu.al
}

\section{Oltion Korini}

Epoka University, Tirana-Rinas, Km 12, 1039, Tirana, Albania

e-mail: oltion.korini@gmail.com

\section{Alban Kuriqi}

Illyrian Consulting Engineers, Rr. Andon Zako Cajupi, Nd. 14, H. 14, Ap. 2 Postal Code 1019, Tirana,, Albania

e-mail: alban.kuriqi@ice.al

\section{Introduction}

Berati town is located in central part of Albania. It is one of the oldest towns in Europe. Due to its unique and older architectonics value, currently it is under UNESCO protection. Mass movements phenomena in urban area of Berati town have been present for a long period. So, from earthquake of October 12, 1851 [21], in the upper part of Castle and Gorica hills were detached; many limestone blocks, cobbles and pebbles fell demolishing several buildings that were located on hill downslopes. During rainstorms, onto these slopes have occurred the rocks falls phenomenon threatening engineering objects and human life. After 1990, as results of manmade works, on urban area's hill's slopes have been occurred several landslides, which have damaged many buildings, urban roads and greens parks. This was the main reason that during the period 20052010 [12,14, 17], several engineering geological and geophysical studies were undertaken in order to recommend building protection measures against landslide occurrences, thus preserving urban development of Berati town. From these studies are defined, the stable and unstable hazardous areas; the necessary engineering measures are also recommended for the hazardous areas. The purpose of this paper is to present an approach, where is investigated and estimated mass movement phenomenon and slope stability in Berati urban area.

\section{Methodology}

Based on demands of Berati, town hall and foreign institute engineers have undertaken several geoengineering and geotechnical studies. The purpose of these studies was the identification of mass movements and their spatial distribution. In addition there are conducted certain geotechnical analyses and investigations of hills slopes for recognition of stable and unstable areas, as well as necessary engineering measures crucial for the protection of buildings, roads and human life as well. The work was done in three phases: desk study, field works and laboratory tests, as well as the interpretation of the data taken from field and laboratory works [1]. Firstly, all previous works done herein are taken into consideration.

After that, the work was conducted in the field, where was 
carried out a detailed engineering geological mapping on scale 1:10 000 [13], followed by a geophysical investigations such as Electrical Resistance (Tomography-ERT), Electrical Resistance Tomography investigation and Seismic measurements-velocity of shear and longitudinal waves, Vs and $\mathrm{Vp}$ [17]. In the third phase the interpretation of the data taken from field laboratory works was completed, from which was compiled engineering geological zoning map on scale 1:10 000 and its text, as well, as hill slope stability maps on scale $1: 5000 \& 1: 10000$ [13, 14]. Engineering geological mapping includes works carried out on oriented profiles for documentation of land's surface according to lithology, geomorphology (alluvial terraces, hills and hills slopes etc.), geodynamics phenomena (mass movements, weathering crust, karstic process, discontinuities and erosions), hydrogeological features (underground water table and aggressive), rock structure, tectonics and seismic activity, as well as drilling; many soil and rock samples were taken for the physicalmechanical properties examined in laboratory. According to the project details on orientated profiles, data for soil and rocks, as well as landslide distribution and configuration were obtained. After finishing the aforementioned works in selected areas of landslide body, 47 boreholes were executed on hill slopes and river terraces. The boreholes were generally drilled from 7.5 up to $20.0 \mathrm{~m}$ deep underground. However, for landslide exploration the boreholes were drilled from 7.5 up to $10.80 \mathrm{~m}$. For the examination of physical-mechanical properties of soils and rocks, from the drilling works in different level of soil profiles were collected 57 samples (36 undisturbed samples and 21 disturbed samples). The soils and rocks samples were analysed in the laboratory for physical and mechanical properties such as grain size, $\gamma$-bulk density, $\gamma$ o-specific gravity, w-natural water content, $\varphi$-internal friction angle, c-cohesion, E-deformation module, $\mathrm{E}_{e l}$-elastic module and $\sigma$-uniaxial compressive strength, etc. The lithological profile of the studied area has been correctly determined from drilling works, and particularly the slide plane depth of the mass movements, which differ from one to each other.

Electrical Resistance Tomography-(ERT) profiles were carried out using a multicore cable with the Dipole-Dipole array. The ERT profiles are utilized for evaluation of the thickness of the landslides, the thickness of the soils in hills slopes and the weathering crust of limestone rock, as well (castle and Gorica hills). The true resistivity images of the subsurface, show a good agreement with the geological engineering methods used. From ERT profile carried out in landslide as indicated in the (Fig. 17), is noticed low resistivity values $(<100 \mathrm{ohm})$ from the surface up to a depth $7.0-8.0 \mathrm{~m}$ in longitudinal profile. It means that this lithological profile consists of soils and weathering crust, in accordance with result of the boreholes done over here. From 7.0 $8.0 \mathrm{~m}$ and deeper is noticed high resistivity values $(>100 \mathrm{ohm})$, which account for the bedrock, flysch rocks as indicated in the (Fig.11). The same resistivity values are observed on other landslides, and areas on flysch rocks. The only difference between profiles is the depth of soils and weathering crust of flysch rocks. To estimate the thickness of the limestone's weathering crust at Castle hill-rocks fall as indicated in the (Fig. 1p), the same ERT techniques has been used. The upper part of ERT profiles show low resistivity values $(<1300 \mathrm{ohm})$ which are characteristic of fractured and karstic limestone filled with soils. The thickness of this layer range from $2.8-4.0 \mathrm{~m}$ up to $4.5 \mathrm{~m}$ and below this layer; we see high resistivity values ( $>1300 \mathrm{ohm})$ typical of fresh limestone as indicated in the (Fig. 1p).

Seismic investigations were performed by application of refraction seismic method. Most of the seismic investigations were carried out on same sites of hills slopes [17], where the ERT measurements for determination of lithological profile took place. Refraction investigations were carried out by means of the Geometrics Smart-Seismic; 12-channel computerized seismic system, using vertical geophones of 20 up to $40 \mathrm{~Hz}$ and hammer blows on a wooden plate for generation of seismic waves. Refraction measurements were performed on profiles $72 \mathrm{~m}$ long, with 24 geophones of $3 \mathrm{~m}$ spacing used, for " $\mathrm{S}$ " and "P" wave determination. Depending on the length of the profile, the measurements involved the surface layers up to the depth of about $15.0 \mathrm{~m}$. Results of seismic surveys have shown that the upper layer (diluvial soils) of lithological profile with thickness $3.8-8.0 \mathrm{~m}$ has a $\mathrm{S}$-wave velocity ranging from 150 to $270 \mathrm{~m} / \mathrm{s}$ to $380 \mathrm{~m} / \mathrm{s}$, while in flysch rocks it was $718-849 \mathrm{~m} / \mathrm{s}$ [17]. Whereas, P-wave was found respectively $250-530 \mathrm{~m} / \mathrm{s}$ and $1650-2750 \mathrm{~m} / \mathrm{s}$ in upper layer (soils) and flysch rock [17]. From these measurements we have determined exactly the boundary between soils and flysch rocks, as well as the slide plane, where the seismic refraction points represent the sliding and soils depth. The slope stability evaluation in the area of Berati town has been performed after in-situ observation and laboratory tests. For the analysis of the slopes stability was used the finite element software Phase2 [19]. Uniform meshing and 6-noded triangles are used in FEM analysis.

The slope stability analysis was completed on engineering geology zones with a basement built of flysch and limestone rocks Finally, based on safety factor values is compiled the slope stability zonation map of Berati town in case of the earthquakes and rainfalls occurrence at the same time, scale 1:5000.

\section{Geological Settings}

In the investigated area different types of sedimentary formations are found (Fig. 2). In the course of the geodynamic evolution, the studied area was subjected to several tectonic activity phases. From our engineering geological mapping [13], are distinguished the Quaternary $(\mathrm{Q})$ deposits, flysch formations of Lower-Upper Oligocene- $\left(\mathrm{Pg}_{3}^{1}-\mathrm{Pg}_{3}^{3}\right)$ and limestone rocks of Eocene $\left(\mathrm{Pg}_{2}\right)$ composed by thin to thick strata. The Quaternary deposits are represented by alluvium and diluvial soils. Alluvium deposits are extended along of the main water course, the river bed of Osumi. The alluvium soils are composed by mixtures of sands and gravels; whereas, the diluvium deposits are 

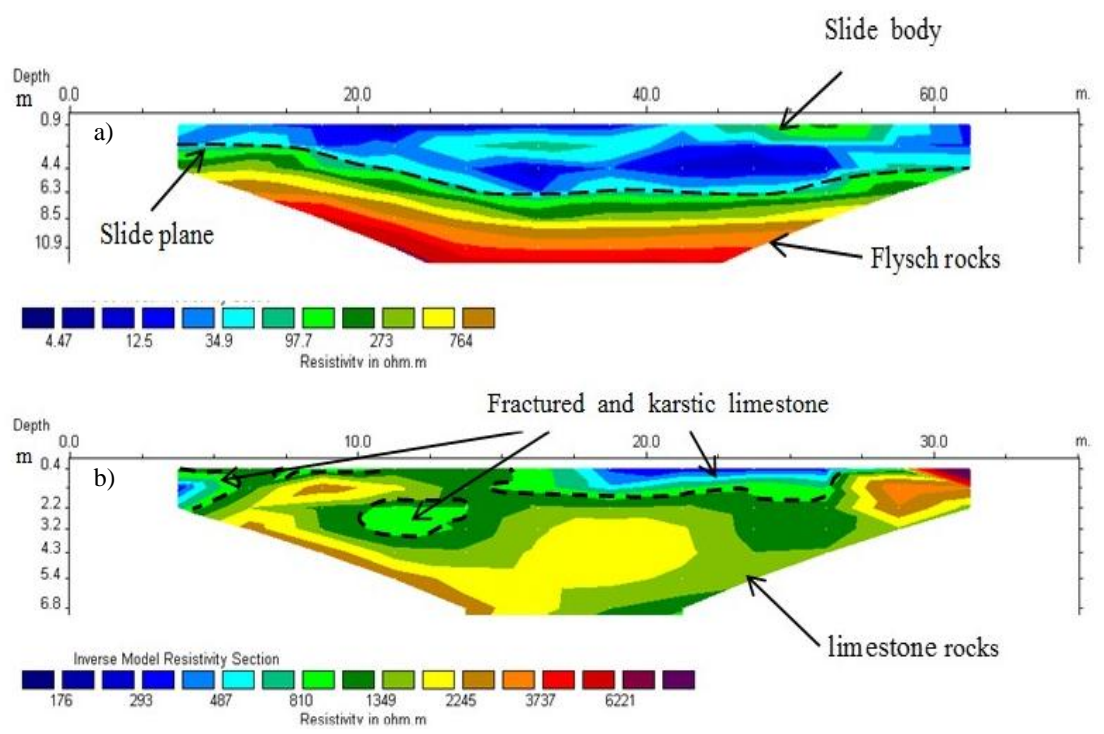

Fig. 1. ERT profile carried out: a) landslide area, b) weathered limestone

composed of inorganic silts and clays with sandstone pebble contents. Generally they are developed along the hilly slopes. The thickness ranges from 1.5-3.0 $\mathrm{m}$ to $4.5-8.5 \mathrm{~m}$. Flysch formations occupy most of whole studied region. They are represented by combinations of thin siltstones, clay stones and sandstones layers. These deposits are normally situated over Eocene's limestones. The siltstones, clay stones and sandstones layers have a thickness $2.0-3.0 \mathrm{~cm}$ up to $5.0-7.0 \mathrm{~cm}$. Most of these rocks covered by Quaternary deposits consist of soils (silt, clay, sandy clay etc.). Limestone's rocks consist of thin and thick strata, mainly of biomicrite-skeleton type intercalated with turbidities limestone strata. The Limestone rocks in the studied area form the asymmetric Berati anticline structure which extends from northwest to southeast with west limb dip with angle $35-37^{\circ}$ and east limb with dip angle $50-52^{\circ}$.

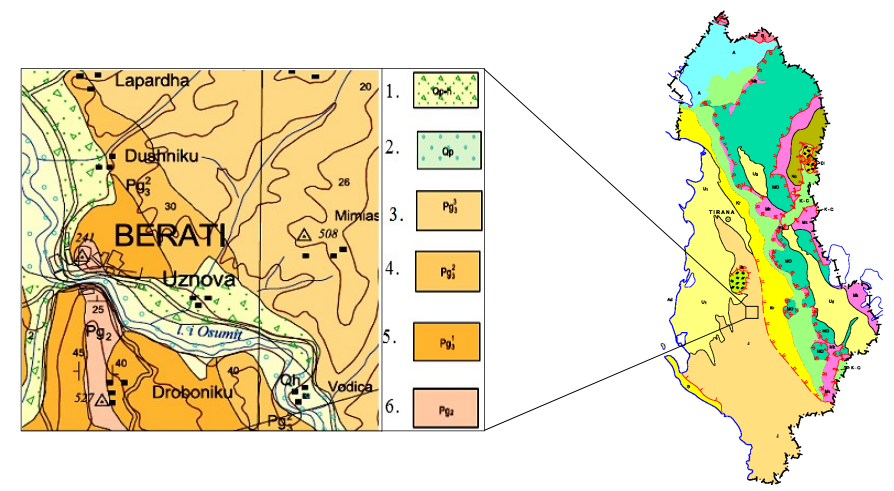

Fig. 2. Geological map of study area.1. Mixture of inorganics silts and clays with gravels, 2. Gravels, 3, 4, and 5. Flysch rocks of Oligocene, 6. Limestone rocks of Eocene

\section{Morphological Setting}

The morphology of the studied area is closely related to the geology. It is represents a hilly-flat zone. Osumi River has created its valley in the center of this hill zone. It is a wide valley with "U" shape. The valley's bed forms a flat area that extends between Castle-Uznove and Gorica-Droboniku hills chains located way above the sea level that ranges from $200.0-250.0 \mathrm{~m}$ up to $450.0-530.0 \mathrm{~m}$. The flat area from geomorphological point of view represents an eroded valley from Osumi River (Fig. 3).

Based on morphological features, the flat morphological unit with inclination angel smaller than $5^{\circ}$ (very slight) is represented by the first and second terrace of Osumi River; it is composed of inorganics silts and clays in upper part and sands, gravel soils in medium and lower part of lithological profile. They are situated on flysch rocks which are $5.0-10.0 \mathrm{~m}$ up to $15.0 \mathrm{~m}$ thick. On the other hand, the hills morphological unit extending on both side of Osumi River is represented by hill chains extending from northwest to southeast. Mostly of these hills are built of flysch rocks generally are covered in soils. In the central part of urban area located the Castle and Gorica hills, built by thin layered limestones. It very important to mention that the hills slopes angles range from $10^{\circ}-20^{\circ}$ up to $30^{\circ}-35^{\circ}$ and in Castle and Gorica hills it is very steep $65-75^{\circ}$ up to $80-87^{\circ}$.

\section{Mass movement}

During field and laboratory works a particular attention was paid to relations between geological structure and slope orientation, slope inclinations angle, underground water depth, soils thickness and soils rocks geotechnical properties. From engineering geological studies [13], resulted the most of hill areas of studied zone was characterized by stable slopes as indicated in the (Fig. 4. 57 and 5b), even that, in some parts they are subject to a mass movement processes that exhibit a different mechanisms, volumes, and movement rates (Fig. 4. 55). The mass movement occurrences on this zone and their spreading, point out that this activity here is closed related to geomorphology, lithology, geological structure, geotechnical properties of rocks and soils, neotectonics and seismicity activity, precipita- 


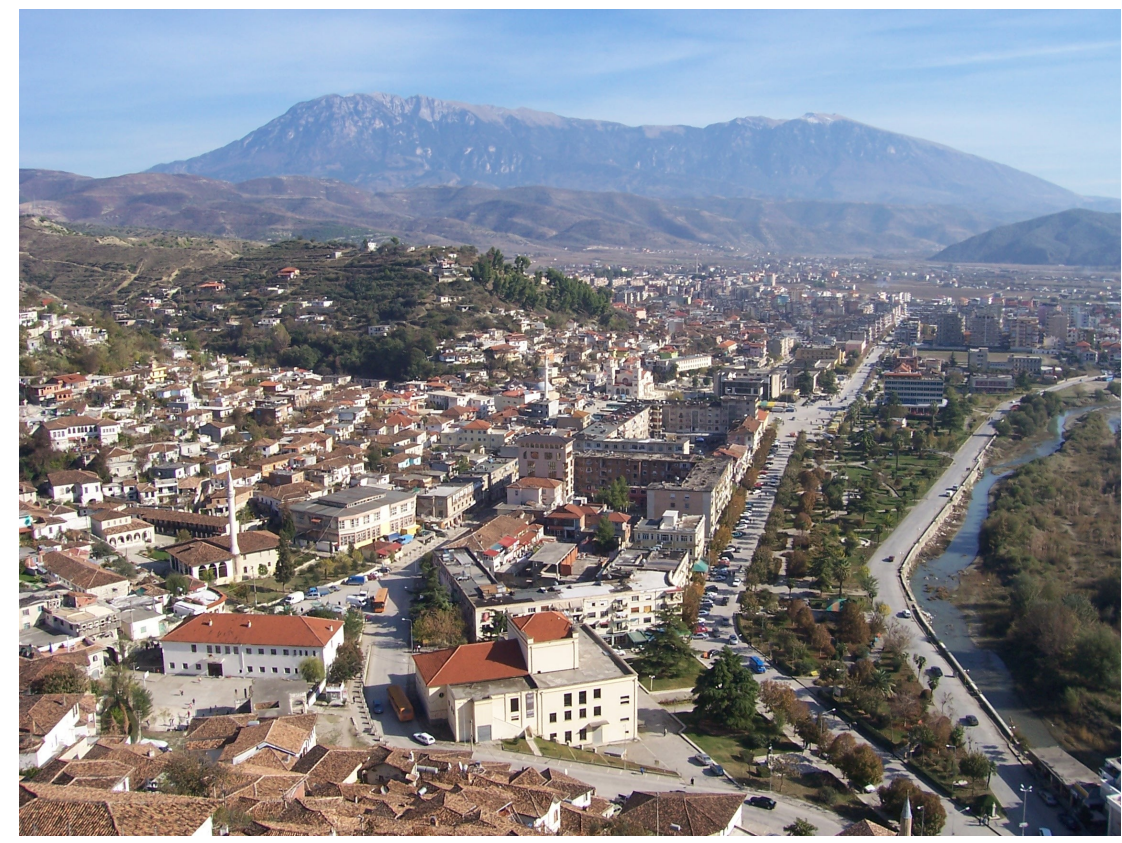

Fig. 3. Geomorphology of the Berati region, sourrounding hills and Osumi River valley

tion events and man-made works. It's very important to emphasize that, mostly of studied area is generally built from rocks with low geotechnical parameters-soft rocks, which induce the mass movement phenomena. Furthermore, it is subject to the occurrence of many earthquakes with magnitude range from 4.6-5.0 [22], up to 6.3 and rainfall in high quantities that are $1200-1300 \mathrm{~mm} /$ year [6, 20], which are the main causes of mass movements [15], in studied area. From the field work data, it results that over the studied zone have occurred several landslides. They are classified according to [2], in earth slide and rock fall types (Fig. 4, 5, and 6).

\subsection{Earth slide}

The center and northeastern parts of urban area is affected from numerous earth slides that have occurred in the hilly slopes built by flysch rocks as indicated in the (Fig. 4, 56). The earth slides in the area have occurred due to interaction of several geofactors such as rainfall, terrain morphology (inclination angle and shape of hilly slope), and human intervention through the hilly slopes. It is very important to note that in this area landslides have started about 50 years ago, but only over the last 20 years the earth slides have increased as a result of human intervention on the hilly slopes for construction purposes. That was the reason, why we have done a lot of engineering geological and geophysical investigations [13, 17]. From the execution of these works it was enabled the determination of the exact slides plan, and the taking a series of soils and rock specimens for analysis in the laboratory according to geotechnical properties. So, it was found that the slide plane had occurred into or in border between weathering crust and soft rocks-flysch (Fig. 55). Also, the field works provided data on the landslides distribution and characteristics, slides plane and weathering crust of flysch rocks. The earth slides are 50.0-90.0 m long, 70.0 - $120.0 \mathrm{~m}$ wide and
4.5 - $8.1 \mathrm{~m}$ deep. The body materials are inorganic silts and clays with pebbles. The weathering crust of flysch rocks ranges from $1.0-1.8 \mathrm{~m}$ up to $3.0-3.5 \mathrm{~m}$. The rupture's surface extends on claystone-siltstone formations and the state of earth slide activity is active. Most of these earth slide occurrences do happen during heavy rain periods because of reactivated movingdown slope. Moreover, as mentioned above; Berati's urban area is characterized by high rainfall (1200-1300 mm/year), which precipitate in the December-April period [20]. Hence, Berati's urban area is under threat from these phenomena.

\subsection{Rock falls}

Among geodynamic phenomena in the studied area are rocks topple and rock falls. These phenomena occurred on both sides of Osumi River valley, at Castle and Gorica hill slopes, on the lower part of which are built the Gorica and Mangalemi squares (Fig. 4 and 6). The valley's slopes are very steep with inclination angle ranging from $65-75^{\circ}$ up to $85-90^{\circ}$. They are built by thin-thick layered limestone rocks, which form the Berati anticline. They are ready to detach and fall down the slope in the possible event of heavy rain and/or earthquakes. Rock fall phenomena in Berati town, Castle and Gorica hills slopes typically occur more frequently during winter and spring months due to rains in form of cloudburst storms. This phenomenon poses a hazard in Berati urban area at Castle and Gorica hills slopes because of a number of people that are living, working, and recreating in down slope of the hills. It was observed from historical data and geotechnical studies that limestone blocks, rocks fragments and boulders accelerate rapidly when dislodged from upper and medium part of hillsides causing a significant damage to homes, life loss, property, roadways and vehicles. Several detailed studies are carried out for evaluation of rock fall hazard in the investigated slopes. Such studies, that are engineering geo- 

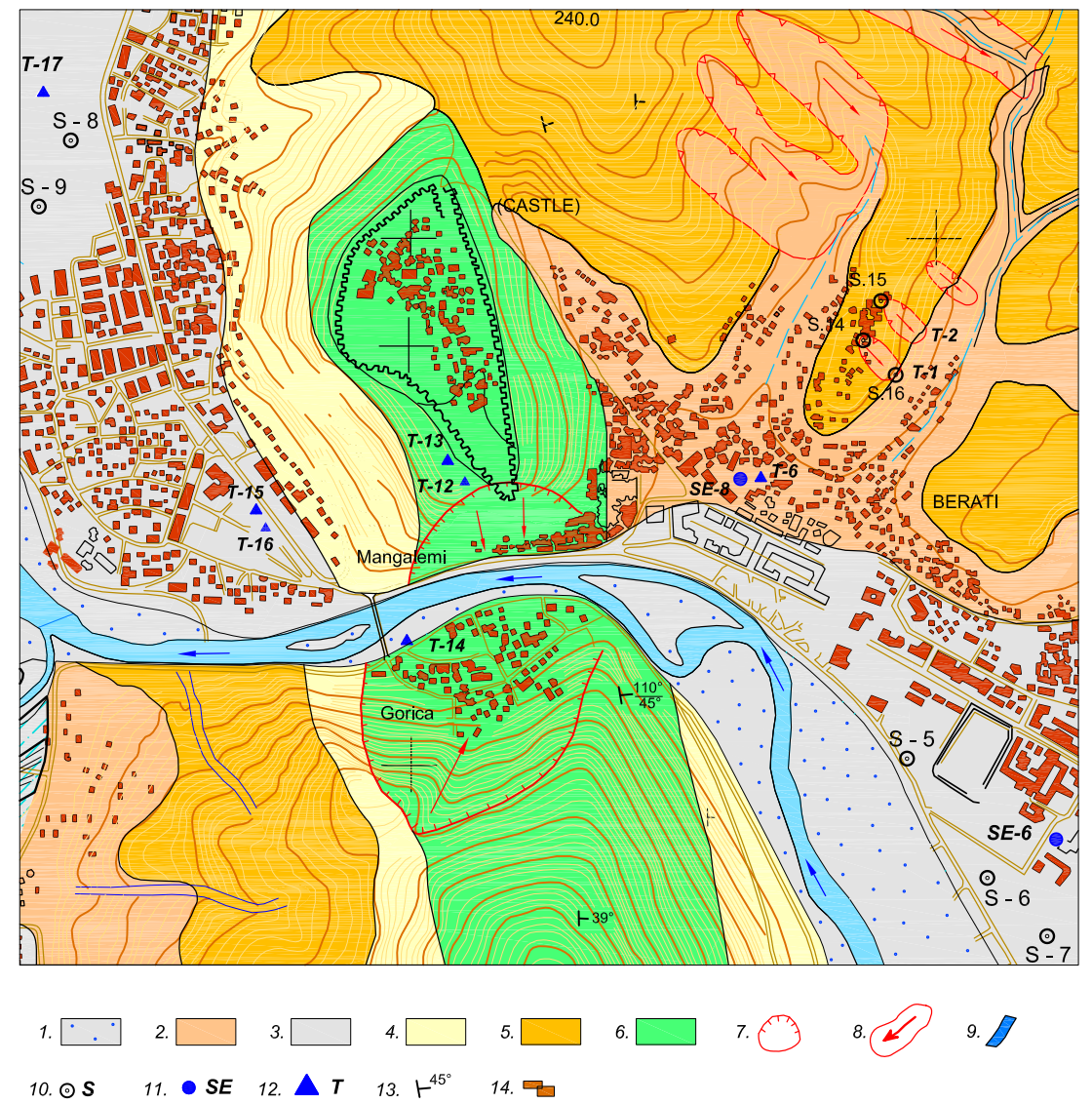

Fig. 4. Engineering geological zoning map of Berati area. 1. River bed soils, gravels, 2. Inorganic silts and clays situated on flysch rocks, 3. First terrace of Osumi River, inorganic silts, 4. Gravels silts situated on limestone rocks, 5.
Flysch rocks, 6. Limestone rocks, 7. Rock fall, 8. Earth slides, 9. River, 10. Engineering geological borehole, 11. Electrical sound (SE), 12. Electrical resistance tomography-ERT, 13. Strata dip angle, 14. Buildings.
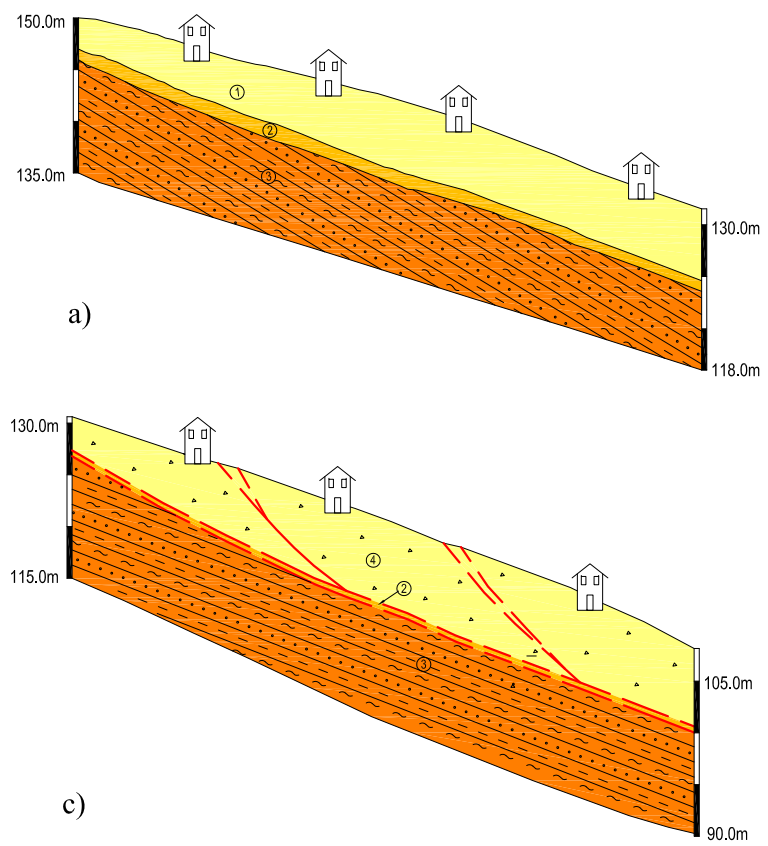

Fig. 5. Lithological profile of engineering geology zone built of flysch rocks. 1. Inorganic silts and clay, 2. Weathered crust of flysch rocks, 3. Flysch rocks-

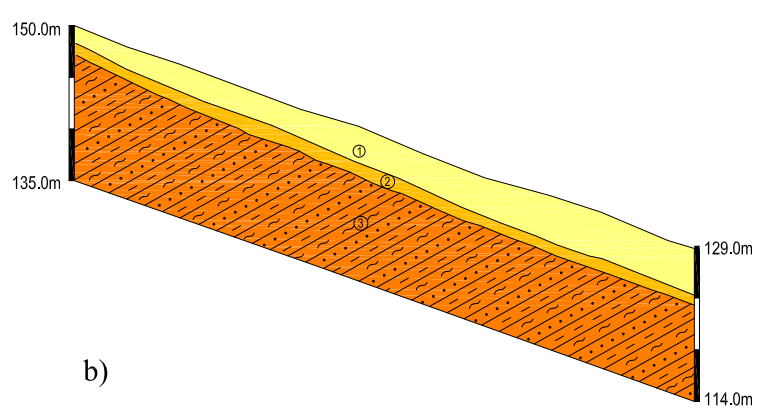

1. $\square$ 2. $\square$ 3. $\square$ 4.

combination of thin clay stones-siltstones layers with sandstones, 4.earth slides body, 5 . Slide plane 
logical mapping [13,17], geophysical measurements and laboratory tests, which have given a qualitative and relative evaluation of rock fall and its hazardous probability in urban area of Berati town. The engineering geological investigations carried out on Castle and Gorica hills slopes have pointed out that the limestones on these areas are intensively fractured from joints, which have divided them in different sizes varying from $5.0-10.0 \mathrm{~cm}^{3}$ up to $1.0-2.5 \mathrm{~m}^{3}$ (Fig. 7).

Geotechnical evaluation and combined results of geotechnical and historical analyses were used to estimate the hazardous areas for this town. Knowing the geotechnical properties of limestone rocks (groundwater characteristics, joints spacing and conditions, weathering crust and karstic degree), slopes characteristic and the propagation probability to any point downhill of rocks and also the mass probability of a given rock volume in the slope, we did forecast and assess the hazard coming from this phenomenon: rock fall initiated due to factors such as rain and earthquakes.

This was very important and useful for citizens that are living in the Berati town and neighboring areas. However, avoidance of rock fall occurrences always has been an option, especially for existing developments. From our studies it was concluded that it is absolutely necessary to use engineering measures for the control and reduction of potential threat from rock falls. Rock-stabilization methods are physical means of hazard reducing at the source using rock bolts and steel mesh. Other engineering measures previously used such as benches and concrete walls, typically placed below source areas, were not efficient due to the limestone blocks, rocks fragments and boulders bouncing over these barriers and damaging the buildings, roads and parks.

\section{Geotechnical analysis}

Based on factors which influence the slope stability of a rock and soils mass, a geotechnical analysis was aimed to detect potentially unstable hill slopes and classify them according to their failure characteristics. The finding potential rock fall sources and earth slide distribution are based on the detailed geotechnical investigations carried out on unstable hills slopes [14], and works of engineering geological mapping on a scale 1:10000, as indicated in the (Fig. 4), completed for the purpose of urban development and seismic micro-zoning of Berati town [13], From these works are obtained very important data which allow us to identify the failure configurations and indications of present movements.

Also, these data were used to precisely localize and define potentially unstable soils and rock masses that are evaluated individually related to their dimensions and volume. For laboratory analyses of limestone rocks, 31 specimens in Gorica and Castles hills slopes were taken. Regularly shaped specimens were tested (cubic $70 \mathrm{~mm}$ ) for physical and mechanical properties.

A special attention is paid to the earth slide phenomenon occurring over flysch rocks slope; a lot of boreholes with depth 7.5 up to $11.0 \mathrm{~m}$, (Fig. 4. 5k), were drilled, from where are taken
78 undisturbed and 29 disturbed soils and rocks (flysch) specimens. The soils and rocks specimens were analyzed in the laboratory for physical and mechanical properties such as granulometry, $\gamma$-bulk density, $\gamma_{0}$-specific gravity, w-natural water content, $\varphi$-internal friction angle, c-cohesion, E-deformation module, Eel-elastic module and $\sigma$-uniaxial compressive strength, etc. The mean results of physical and mechanical properties of limestone's and flysch rocks are shown respectively in (Tables 1, 2 and 3). From engineering geological mapping, [13] the urban area was divided into flat and hilly morphological units (Fig. 4). In this paper we analyze the geotechnical conditions of hilly morphological unit because of its relationship to unstable slopes.

According to lithological features the hilly morphological unit was classified in two engineering geology zones which are:

a. The engineering geology zone with a basement built of flysch rocks (Fig. 4).

b. The engineering geology zone with a basement built of limestone rocks (Fig. 4).

a. The engineering geology zone with a basement built of flysch rocks (Fig. 4, 5).

It is extended in north, east and southwest of urban area. Most of this zone is built by slopes with inclination angle range from $12^{\circ}-20^{\circ}$ up to $25-29^{\circ}$. They generally are occupied by diluvium soils, which are $1.5-3.5 \mathrm{~m}$ up to $5.5-8.0 \mathrm{~m}$ thick. Based in fields works and laboratories test results (Table 1), in this zone are distinguished several geotechnical units, which are described in details as follows (Fig. 5):

Geotechnical unit 1, lies in upper part of lithological profile (Fig. 5a, and 5p). It is composed by the inorganic silts and very fine sands (ML type, after ASTM D2487-00) and inorganic clays of low to medium plasticity (CL type, after ASTM D2487$00)$ with very stiff to hard consistency, medium water content, and beige color.

Geotechnical unit 2, is situated on geotechnical unit 3 (Fig. 5a, 5p and 5k). The soils represent the weathered crust of flysch rocks, which is $1.2-1.5 \mathrm{~m}$ up to $2.0 \mathrm{~m}$ thick. They consist of inorganic silts with low plasticity and very fine sands (ML type, after ASTM D2487-00), less water content, hard consistency and grey to beige color. These soils are ML type.

Geotechnical unit 3, builds the lower part of lithological profile (Fig. 5a, 5 b and 5k).

It is consisted of very weak rocks [8], which are flysch rockscombination of thin clay stones-siltstones layers with sandstones.

Geotechnical unit 4, represents the slide's material (Fig. 4p), which consists of inorganic silts of low to medium plasticity and fine to medium sands (ML type, after ASTM D2487-00) with gravels content, medium-stiff consistency, medium-high water content, and beige color.

b. The engineering geology zone with a basement built of limestone rocks (Fig. 4,6).

It is located in center part of Berati town. This zone is 


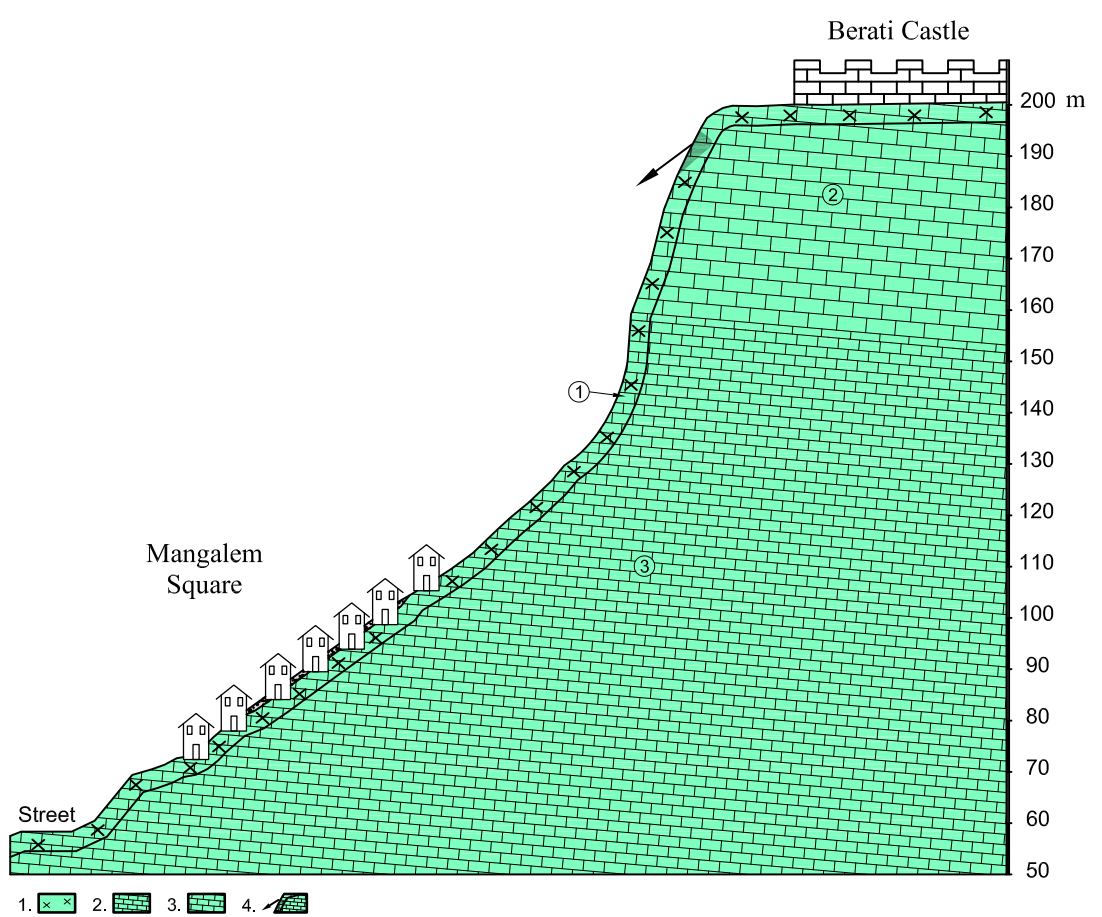

Fig. 6. Lithological profile of engineering geology zone built of limestone

2. Thick bedding limestone, 3 . Thin bedding limestone, 4. Rocks fall. rocks (rocks fall in Mangalem square) 1. Weathering crust of bedding limestone

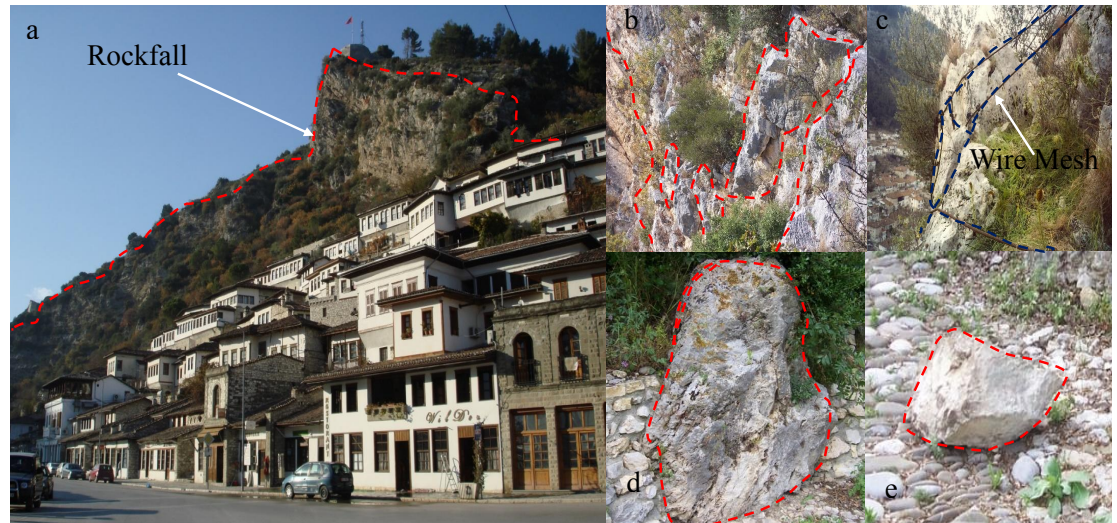

Fig. 7. It shows the Mangalem square, a) rock fall area, b) weathered rocks, October 12, 1851 earthquake, e) rocks mass detached from hills during January, c) rock mass retained with wire mesh, d) rocks mass detached from hills during February and April 2010 high intensity rainfall events

Tab. 1. Geotechnical properties of soils and rocks of engineering geology zone built of flysch

\begin{tabular}{|c|c|c|c|c|c|c|c|c|}
\hline \multirow{3}{*}{ Properties } & \multirow{3}{*}{ Unit } & \multicolumn{6}{|c|}{ Soils-highly weathered } & dy soils \\
\hline & & \multicolumn{2}{|c|}{ Geotechnic unit 1} & \multicolumn{2}{|c|}{ Geotechnic unit 2} & \multirow{2}{*}{$\begin{array}{c}\text { Flysch } \\
\text { Geotechnic } \\
\text { unit } 3 \\
\end{array}$} & \multicolumn{2}{|c|}{ Geotechnic unit 4} \\
\hline & & peak & residual & peak & residual & & peak & residual \\
\hline$\gamma$ & $\mathrm{kN} / \mathrm{m}^{3}$ & $19.5-19.7$ & - & $20.3-21.8$ & - & $21.7-24.1$ & $17.9-18.1$ & - \\
\hline$\varphi$ & $\circ$ & $19-21$ & $14-16$ & $27-29$ & 26.2 & $28-32$ & $13-15$ & $11-13$ \\
\hline $\mathrm{c}$ & $\mathrm{MPa}$ & $0.065-0.075$ & $0.021-0.023$ & $0.071-0.11$ & 0.024 & $0.12-0.15$ & $0.01-0.015$ & $0.007-0.009$ \\
\hline$v$ & & 0.29 & - & - & 0.27 & $0.23-0.24$ & 0.33 & - \\
\hline $\mathrm{E}$ & $\mathrm{MPa}$ & $30.7-36.9$ & $28.5-35.0$ & $51.8-64.3$ & $45.0-55.0$ & - & $4.23-4.57$ & $3.89-4.13$ \\
\hline $\mathrm{E}_{e l}$ & $\mathrm{MPa}$ & $48.8-58.5$ & - & $83.2-92.9$ & - & - & $12.5-24.4$ & - \\
\hline$\sigma$ & $\mathrm{MPa}$ & - & - & - & - & - & - & $2.34-3.25$ \\
\hline
\end{tabular}

* $\gamma$-bulk density, $\varphi$-internal friction angle, c-cohesion, $\nu$-poisson ratio, E-deformation module, Eel-elastic module, $\sigma$-uniaxial compressive strength. 
built of two steep slopes (Berati Castle and Gorica hills), which have an inclination angle range from $25-35^{\circ}$ (down part) up to $75-90^{\circ}$ (upper part). The four geotechnical units were determined from laboratory and field works completed on this zone. Geotechnical unit 1 is weathering crust $(2.5-3.8 \mathrm{~m}$ up to $4.5 \mathrm{~m}$ thick) of bedding limestone rocks (Fig. 6, 12 1 ). It was concluded from geotechnical investigations that these limestones are slightly-moderately weathered and much affected by cracks and karst phenomena (Fig. 11p), which are filled by soilsclays. According to geomechanical classifications these rocks are weak (Hoek et al. 1998).

Geotechnical unit 2, represents the thick bedding limestone rocks, which are situated in upper part of lithological profile (Figs. 6 and 12 a). According to geomechanical classification these rocks are high strength (Farah et al. 2013).

Geotechnical unit 3, is composed of thin bedding limestone rocks that are lain under of the thick bedding limestone rocks (Fig. 6). According to geomechanical classification these rocks are medium up to strong (Hoek et al. 1998).

Geotechnical unit 4, is represented by diluvial soils, (Figs. 4 and 6, which are the gravels clays (CL type, after ASTM D2487-00) with cobles and boulders mixtures with hard consistency. This geotechnical unit is extended on both side of limestone rocks on hill slopes with inclination angle $35-55^{\circ}$. From engineering geological investigations, it was concluded that this geotechnical unit is in stable condition. Hereinafter, we are analyzing in details the first geotechnical unit (weathering crust of bedding limestone rocks) because of the toppling and rocks fall phenomena are linked to this unit. From engineering geological mapping, it was observed that the limestone rocks (geotechnical unit 1) are affected by three joints systems which are as following:

i). the first joints systems coinciding with limestone beddings. Situated in the east limb of anticline structure the joints of this group have the strike $\mathrm{NW}\left(335^{\circ}\right)$ - $\mathrm{SE}\left(165^{\circ}\right)$ with dip angle $50^{\circ}$ to northeast direction. Whereas, in the west limb of anticline structure the joints have the strike $\mathrm{NE}\left(300^{\circ}\right)$ to $\mathrm{SW}\left(120^{\circ}\right)$ with dip angle $37^{\circ}$ to southwest direction. The joints have spacing $4.0-10.0 \mathrm{~cm}$ up to $1.8 \mathrm{~m}$. They are characterized by continuous joints, slicken-sided surfaces with aperture $2.0-3.0 \mathrm{~cm}$ to $5.0 \mathrm{~cm}$, filled by clay materials, which have low geotechnical properties (Table 3).

ii). the second joints systems have the strike $\mathrm{NE}\left(40^{\circ}\right)$ $\mathrm{SW}\left(220^{\circ}\right)$ with dip angle $90^{\circ}$. These joints are characterized by $0.7 \mathrm{~m}-1.2 \mathrm{~m}$ spacing, continuous slicken-sided surfaces with aperture width $5.0-10.0 \mathrm{~cm}$, filled by clay materials with low geotechnical properties (Table 3 .

iii). the third joints systems have the strike $\mathrm{SE}\left(115^{\circ}\right)$ $\mathrm{NW}\left(295^{\circ}\right)$ with dip angle $70^{\circ}$ to southwest direction. These joints have $0.4 \mathrm{~m}-0.6 \mathrm{~m}$ spacing, continuous joints with slickensides surfaces with aperture width $0.1-0.3 \mathrm{~cm}$, filled by clay materials with have low geotechnical properties (Table 1, 2, 3).

The presence of bedding limestone, which has an influence on the flow of groundwater (rain), aided by other factors (tectonic movement, freezing, earthquake) caused many cracks parallel and cross layers of limestone, forming snippets and rocky blocks, which are located across the hilly slopes in critical equilibrium state.

Since, this this equilibrium will disbalance, as a result of the action of the factors mentioned above, these snippets and limestone blocks will detach and fall down. Finally, the rock topple and rock falls are scattered throughout the two slopes of Castel and Gorica hills, constitute a real threat to life and human engineering objects such as buildings, roads, etc.

\section{Slope stability analysis}

Based on geomorphological features (slope angle, shape) and physical mechanical properties of soils and rocks, we have computed the safety factor SF (SRF) for all hill slopes that are included in Berati urban area. But in this paper we are presenting the calculation the most representative hill slopes, which can be classified into four types.

1 The underlying rocks strata are inclined toward (parallel and semi parallel) to the natural slopes (Fig. 5a).

2 The underlying rocks strata are inclined anti-dip natural slope (Fig.5p).

3 The hill slopes, which are affected of mass movements (Fig.5p).

4 The hill slopes that are built of limestone rocks and are characterized by mass movements (Figs. 6 and 12 a).

A slope stability evaluation in the area of Berati town has been performed after in-situ observation and laboratory tests. For the analysis of the slopes stability was used the finite element software Phase2 [19]. Uniform meshing and 6-noded triangles are used in FEM analysis. The slope stability analysis was completed on engineering geology zones:

a. engineering geology zone with a basement built of flysch.

b. engineering geology zone with a basement built of limestone rocks.

a. engineering geology zone with a basement built of flysch.

The Mohr-Coulomb failure criterion, [5, 24] is chosen to model the soils and elastic-plastic material properties are used as required by the Shear Strength Reduction (SSR) analysis. In all cases the analysis is split in two stages: stage 1 , which is used to model site stress using plastic analysis and stage 2, which is used for SSR analysis under the effect of a specified hazard. in each of the following conditions: i) heavy rains, ii) seismic activity using PGA hazard value $0.3 \mathrm{~g}$ from the Albanian Seismicity Map [11], iii) both rain and seismic activity. A fully saturated soil represents higher risk for slope failure due to several reasons [25]. Firstly, the wet unit weight is lower than dry unit weight due to Archimedes forces on the soil particles. Secondly, the friction between particles is lowered and, thirdly the cohesion 
Tab. 2. Geotechnical properties of soils and rocks of engineering geology zone built of limestone

\begin{tabular}{cccccc}
\hline \multirow{2}{*}{ Properties } & \multirow{2}{*}{ Unit } & \multicolumn{4}{c}{ Limestone } \\
\cline { 3 - 6 } & & $\begin{array}{c}\text { Geotechnical } \\
\text { unit no. 1 }\end{array}$ & $\begin{array}{c}\text { Geotechnical } \\
\text { unit no. 2 }\end{array}$ & $\begin{array}{c}\text { Geotechnical } \\
\text { unit no. 3 }\end{array}$ & $\begin{array}{c}\text { Geotechnical } \\
\text { unit no. 4 }\end{array}$ \\
\hline$\gamma$ & $\mathrm{kN} / \mathrm{m}^{3}$ & 25.89 & 26.34 & 26.78 & $19.8-20.1$ \\
$\varphi$ & $\circ$ & $38-40$ & $41-43$ & $42-45$ & $24-28$ \\
$\mathrm{c}$ & $\mathrm{MPa}$ & $2.6-4.2$ & $6.76-7.54$ & $7.21-8.74$ & $0.025-0.055$ \\
$v$ & & 0.21 & 0.20 & 0.20 & 0.28 \\
$\sigma$ & $\mathrm{MPa}$ & $12.0-15.0$ & $43.7-48.5$ & $52.6-78.4$ & - \\
\hline${ }^{*} \gamma$-bulk density, $\varphi$-internal friction angle, c-cohesion, $\nu$-poisson ratio, $\sigma$-uniaxial compressive strength.
\end{tabular}

Tab. 3. Geotechnical properties of boundary soils between sandstones \& siltstones of flysch rocks and infilling soils in limestone's fractures

\begin{tabular}{|c|c|c|c|c|c|}
\hline \multirow[t]{2}{*}{ Properties } & \multirow[t]{2}{*}{ Unit } & \multicolumn{2}{|c|}{$\begin{array}{l}\text { Soils between sandstones and } \\
\text { siltstones layers (binding) }\end{array}$} & \multicolumn{2}{|c|}{$\begin{array}{l}\text { Infilling soils in } \\
\text { limestone's fractures }\end{array}$} \\
\hline & & peak & residual & peak & residual \\
\hline$\gamma$ & $\mathrm{kN} / \mathrm{m}^{3}$ & 20.5 & - & 19.2 & - \\
\hline$\varphi$ & $\circ$ & $24-26$ & $21.9-23$ & 18 & 14.6 \\
\hline c & $\mathrm{MPa}$ & $0.03-0.045$ & $0.017-0.020$ & $0.018-0.025$ & $0.012-0.015$ \\
\hline$v$ & & 0.24 & - & 0.30 & - \\
\hline E & $\mathrm{MPa}$ & $90.0-50.0$ & $50.0-55.0$ & $24.3-27.6$ & $22.0-25.0$ \\
\hline $\mathrm{E}_{e l}$ & $\mathrm{MPa}$ & - & - & $42.0-52.0$ & - \\
\hline Thickness & $\mathrm{cm}$ & $0.3-0.6$ & & $0.5-2.5$ & \\
\hline
\end{tabular}

is reduced in cohesive soils. However, the first reason is significant for beginning a slope failure, while the two others are more responsible for displacement and deformation values of the sliding body [10]. Also seismic activity induce a horizontal inertial force which has considerable value for seismic countries like Albania. So it is necessary to include this force. Lastly, the combination of both saturation and seismic force may be rare from a statistical point of view but still it is a possible event. For slopes around permanent constructions it is important to know all their risks so protective means may be developed. Moreover, the relationship between geological structure and slope orientation are taken under consideration in slope stability calculations. Three cases of the analysis results are shown (Figs. 8, 9] and 10, the results are summarized in (Table 4).

No reduction factors are used, so the slope may be considered safe only when $\mathrm{SRF}>1.3$. For the values $\mathrm{SF}=1.0-1.3$, the condition is critical and below $\mathrm{SF}=1.0$ the slope is unstable. Summary of strength reduction, critical SRF variation for certain displacements for all cases is presented below (Fig. 11). $b$. engineering geology zone with a basement built of limestone rocks.

The generalized Hoek-Brown criterion, [4, 23] is used to model the rock slope at the Mangelem square. The thickness of weathered limestone (geotechnical unit 1) varies from 2.8 $4.0 \mathrm{~m}$ up to $4.5 \mathrm{~m}$, (Fig. $12 \mathrm{a}$ ). This geotechnical unit is heavily jointed and the joints are filled with fine grained material. In sporadic parts of the slope there are detached pieces of rock which may fall any moment. In general, there still exist forces of rock cohesion which keep parts together. In order to approach this situation in realistic way, two combined joint networks are used to represent the real situation. The first is fully detached until base rock in $10^{\circ}$ inclination using uniform statistical distribution with mean value $1.1 \mathrm{~m}$ and $0.4 \mathrm{~m}$ variation. The second joint network has $85^{\circ}$ inclination using normal statistical distribution with mean value $1.0 \mathrm{~m}$ and $0.3 \mathrm{~m}$ standard deviation.

This transversal network is assumed not to fully break across the first one but approximately $80 \%$ of it. So the slope will exhibit stability in the absence of outer forces due to this $20 \%$ of remaining unbroken part (Fig. 12p). The used material properties are summarized in Table 5. The geotechnical unit 1 is the weathered and dense fractured limestone (Fig. 12 1 ). The geotechnical unit 2 is the thick bedding limestone rocks (Figs. 12p and 12p). The modeling parameters are generalized as in Hoek-Brown model. The joint properties are derived from Barton-Bandis parameters which are taken in comparison to site investigation and other tests. These parameters then are converted to Mohr-Coulomb using RocData software, the joint properties are shown in (Table 6. A rock joint may exhibit friction and cohesion. Both these parameters depend on joint aperture, infill material and roughness. The current joints are in limestone rock and have a mean friction angle of $31 \mathrm{o}$. The joints aperture have a mean value of $1-5 \mathrm{~mm}$. This derives the conclusion that the joint infill material has little effect on the properties. The joint cohesion is a result of the roughness profile and is observed when the internal edges of the profile block each-other movement. The maximum cohesion is reached just before these joints break and after this moment only friction is present. A roughness JRC of 6 corresponds to $76 \mathrm{kPa}$ cohesion, 
Tab. 4. Slope stability analysis results in engineering geology zone with a basement built of flysch

\begin{tabular}{cccc}
\hline \multirow{2}{*}{ Slope type } & \multicolumn{3}{c}{ Safety Factor in cases } \\
\cline { 2 - 4 } & Rain & Seismic & Rain + Seismic \\
\hline nr.1 & 3.22 & 1.84 & 1.51 \\
nr.2 & 4.49 & 2.40 & 2.27 \\
nr.3 & 0.74 & 0.54 & 0.34 \\
\hline
\end{tabular}

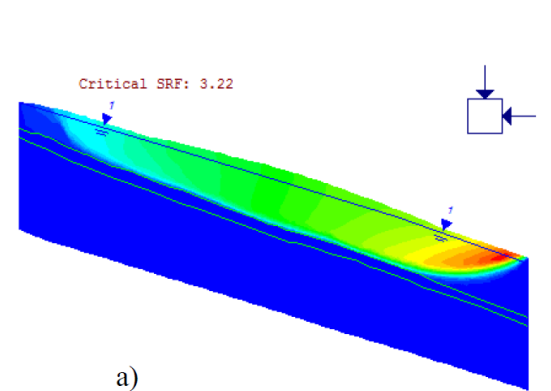

a)
Critical SRF: 1.84

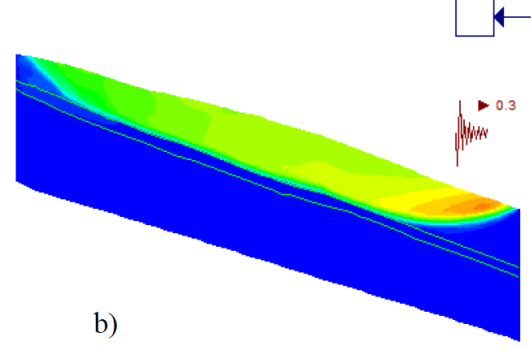

Critical SRF: 1.51

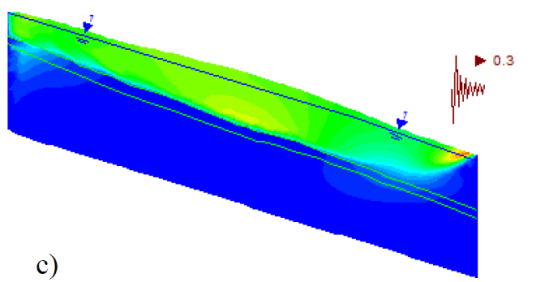

Fig. 8. Model of safety factor computed by finite element in slope type nr. 1 in case of a). saturation, b). PGA and c). saturation + PGA.
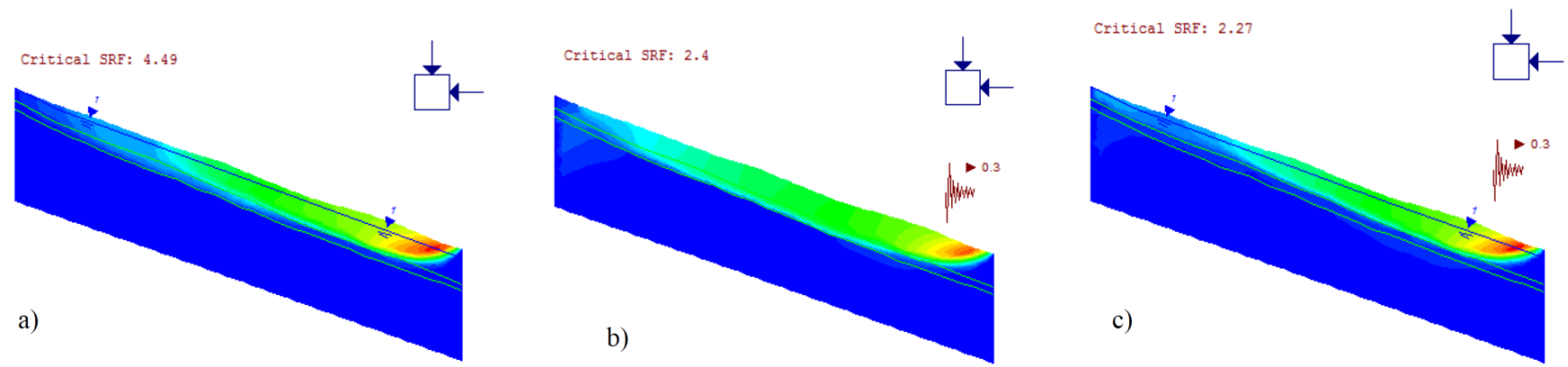

Fig. 9. Model of safety factor computed by finite element in slope type nr. 2 in case of a). saturation, b). PGA and c). saturation + PGA.

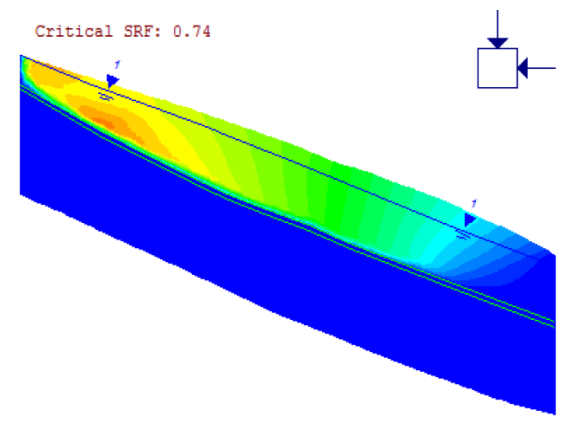

a)

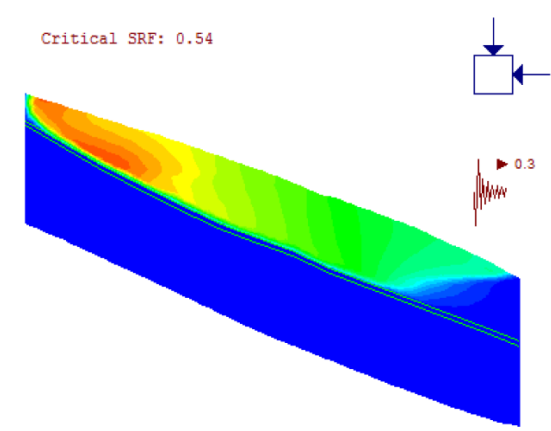

b)

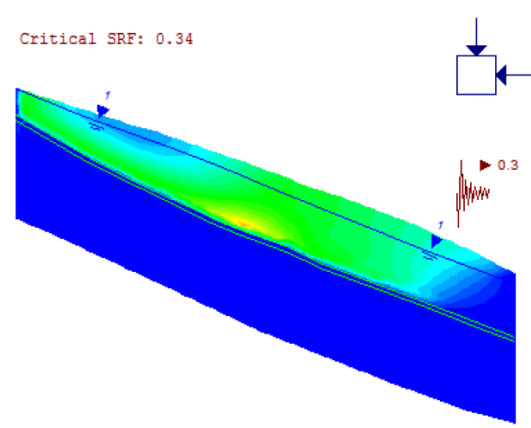

c)

Fig. 10. Model of safety factor computed by finite element in slope type nr. 3 in case of a). saturation, b). PGA and c). saturation + PGA.
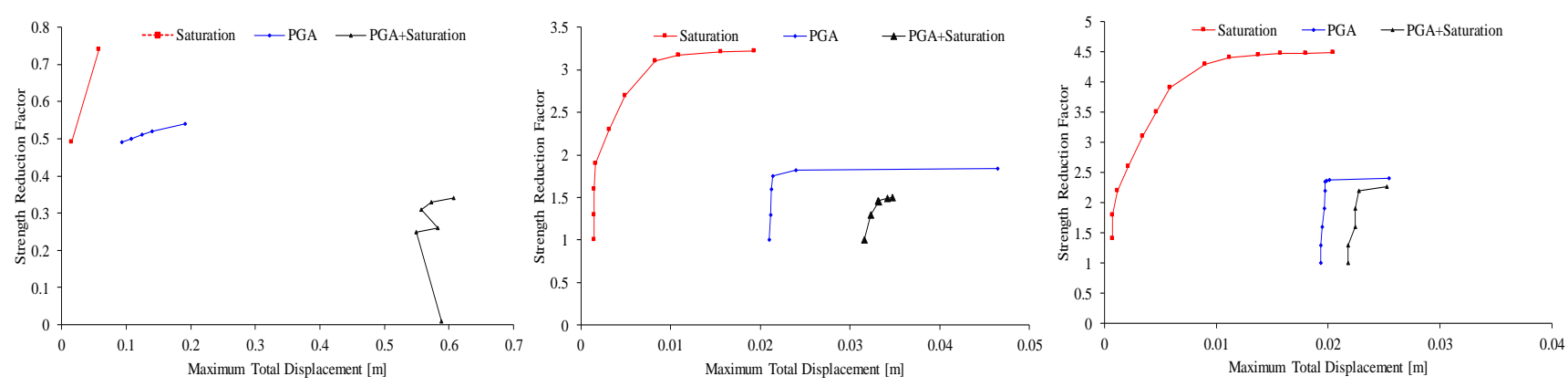

Fig. 11. Shear Strength Reduction Critical SRF, a): $0.74,0.54$ and 0.34 at

$0.019,0.046,0.035 \mathrm{~m}$; c) 4.49, 2.4, 2.27 at Displacement: $0.020,0.025,0.025 \mathrm{~m}$ Displacement: $0.058,0.191,0.607 \mathrm{~m}$; b) $3.22,1.84$ and 1.51 at Displacement: 


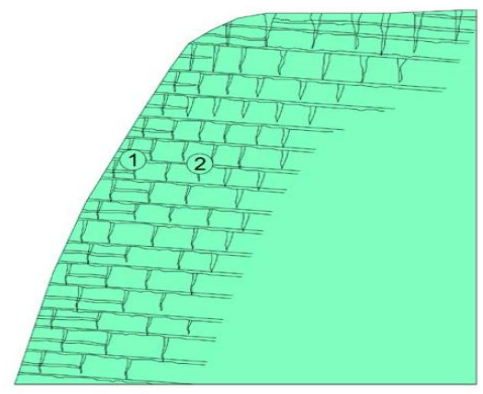

1. 들 2. 대

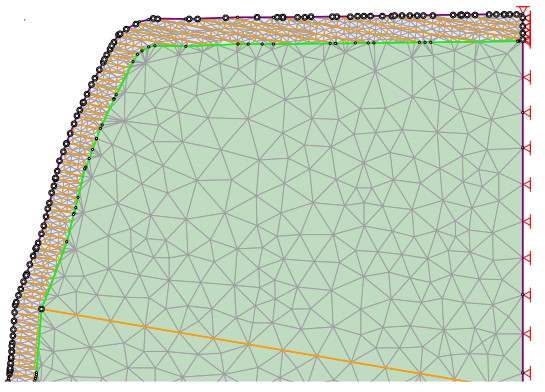

Fig. 12. a). Litological profile of upper part of limestones rocks of castle hill slope (Mangalem squares), b). Slope model, 1 . Weathering crust of bedding

limestone 2. Thick bedding limestone

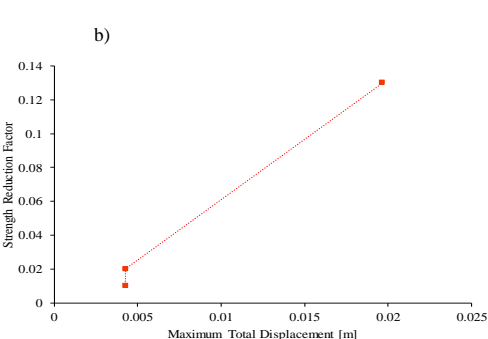

Fig. 13. Representation of a) Total Displacement along the Hill Slope, b) Shear Strength Reduction Critical SRF: 0.13 at Displacement: $0.020 \mathrm{~m}$

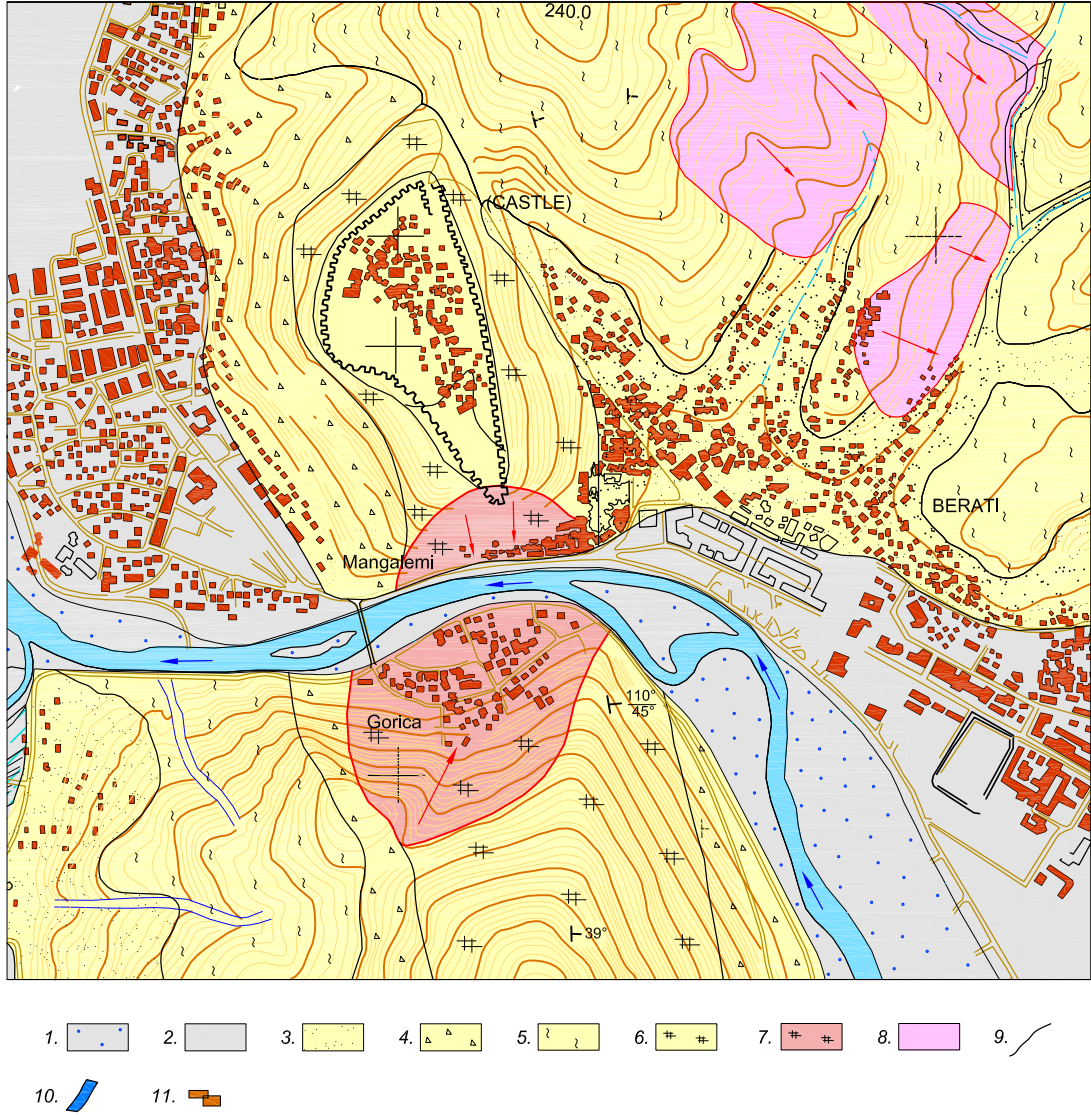

Fig. 14. Slope stability zonation map of Berati town in case of the earthquakes and rainfalls occurrence at the same time, scale 1:50001. Engineering geology Zone of Osumi River bed, stable, 2. Engineering geology zone of first terrace of Osumi River, stable, 3. Engineering geology zone with basement of flysch rocks-soils cover, stable, 4 . Engineering geology zone with basement of limestone rocks-soils cover, stable, 5. Engineering geology zone with basement of limestone's rocks, stable, 6. Engineering geology zone with basement of flysch rocks, stable, 7. Engineering geology site in unstable state-rocks fall. 8. Engineering geology site in unstable state-earth slide, 9. Boundary of engineering geology zone, 10. Osumi River, 11.buildings. 
Tab. 5. Geotechnical properties of limestone rocks

\begin{tabular}{ccccc}
\hline No & Properties & Unit & \multicolumn{2}{c}{ Limestone rocks } \\
\cline { 3 - 5 } & & & geotechnical unit & geotechnical unit \\
\hline 1 & Density $(\gamma)$ & $\mathrm{gr} / \mathrm{cm}^{3}$ & 2.41 & 2.5 \\
2 & Sigci & $\mathrm{MPa}$ & $17-20$ & $40-70$ \\
3 & $\mathrm{GSI}$ & $\mathrm{MPa}$ & 30 & $38-55$ \\
4 & $\mathrm{MPa}$ & 6 & 6 \\
5 & $\mathrm{Di}$ & & 0 & 0 \\
\hline
\end{tabular}

*Density- rock mass unit weight, Sigci-intact rock compressive strength, GSI-Geological Strength Index, mi-material constant for intact rock, D-disturbance factor

Tab. 6. The joint properties

\begin{tabular}{ccccc}
\hline \multirow{2}{*}{ No } & \multicolumn{3}{c}{ Joints Model parameters } \\
\cline { 2 - 5 } & \multicolumn{3}{c}{ Barton- Bandis } & \multicolumn{1}{c}{ Mohr-Coulomb } \\
\hline 1 & $\varphi_{r}$ & $31^{\circ}$ & \multicolumn{1}{c}{$35^{\circ}$} \\
2 & $\mathrm{JRC}$ & 6 & $\mathrm{C}$ & $76 \mathrm{kPa}$ \\
3 & $\mathrm{JCS}$ & $18 \mathrm{MPa}$ & - & \\
\hline${ }^{*} \varphi r$-residual friction angle, JRC-joint roughness coefficient, JCS-joint compressive strength, $\varphi$-joint friction \\
angle, c-joint cohesion
\end{tabular}

which is a relatively low value. Using these data the model is implemented in Phase2 software (Fig. 13). The external loads considered in this case differ from normal soft soil slopes. The rainwater has no possibility to go through all the joint networks due to the small apertures and many times non-communicating joints. So it would not be meaningful to put a water table inside the rock. The only external effect remaining is the seismic force that is significant for the area into consideration. This seismic activity is represented by the PGA hazard value $0.3 \mathrm{~g}$ from the Albanian Seismicity Map. A SSR (Shear Strength Reduction) analysis is performed using PGA $=0.3 \mathrm{~g}$.

The result of slope stability is shown in (Fig. 13), obviously for this value of PGA the slope is unstable in its upper part. As observed the displacements of the range $0.4 \mathrm{~m}$ is large and indicates the full detachment of the upper part of the slope. This phenomenon is very dangerous and should be prevented by using engineering means of protection. A SSR analysis in this case shows a very low safety factor 0.13 (Table 7), due to lack of convergence. This lack of convergence is a result of equilibrium loss of the detached part of the rock.

Tab. 7. Slope stability analysis results in engineering geology zone with a basement built of limestone, Mangalem square

\begin{tabular}{ccc}
\hline No & Slope type & \multicolumn{2}{c}{ Safety Factor } \\
\cline { 3 - 3 } & Seismic case \\
\hline 1 & nr.4 & 0.13 \\
\hline
\end{tabular}

\section{Discussions}

A detailed slopes stability analysis of the hill morphological unit has been done in the urban area of Berati town. The safety factor SF (SRF) was computed for different conditions of geotechnical soils and rocks, which are i) heavy rains, ii) seis- mic activity and iii) heavy rainfall and seismic activity (Fig. 8 9. 10 and 13). On the basis of the safety factor values the hill slopes in Berati urban area, are classified in two categories:

a. Hill slopes in unstable condition $S F<1.0$.

From results of safety factor evaluation, (Table 4 and 7 ) was concluded that some hill slopes in the central and northeastern part of the urban area of Berati, in the case of wet conditions (rainy days) and seismic activity are in unstable conditions. It means that these slopes are characterized by mass movements, which are earth slide and rock fall types. As shown in (Fig. 14), in this group are included the hill slopes, which are built of flysch rocks, as well as the hilly slopes built from limestone, where possible landslides will be occurred in case of wet and seismic activity.

b. Hill slopes in stable condition $S F>1.3$.

In terms of mass movement phenomena the hill slopes, which are involved in this group are stable (Table 4). Fig. 14 shows that the most of the hill morphological unit of the urban area of Berati is characterized by stable slopes.

\section{Conclusions}

Some parts of Berati urban area are affected by the mass movements phenomena represented from: toppling, earth slide and rock fall types. It is concluded that mass movements are caused by manmade works, rain and/or seismic activity. Many engineering objects like buildings, urban roads are damaged from rock falls and earth slides phenomena in center, north and northeast of Berati urban area. To protect the Gorica and Castel squares against rock fall, is absolute necessary to apply protective engineering measures. It is recommended the removal of loose rocks from slopes and the usage of rock bolts and steel mesh as protection from future rock falls. Also, it's necessary 
to apply engineering measures for protection against of earth slides occurrences, such as deep drains for drying the sliding plane combined with sheet-pile retaining walls.

\section{Acknowledgement}

The authors would like to thank the editor Balázs Vásárhelyi and referees for constructive comments that helped to improve the manuscript.

\section{References}

1 Ádám J, Dede K, Heck B, Kutterer H, Mayer M, Seitz K, Szúcs L, GPS deformation measurements in the geodynamic test network Soskut, Civil Engineering, 46(2), (2003), 169-177, DOI 10.1007/s10346-003-0006-9

2 Ayalew L, Yamagishi H, Ugawa N, Landslide susceptibility mapping using GIS-based weighted linear combination, the case in Tsugawa area of Agano River, Niigata Prefecture, Landslides, 1(1), (2004), 73-81.

3 ASTM D2487-00, Standard Practice for classification of soils for engineering purposes, (unified classification system), 4.08, (2003).

4 Carranza-Torres C, Fairhurst C, Application of the convergenceconfinement method of tunnel design to rock masses that satisfy the HoekBrown failure criterion, Tunnelling and Underground Space Technology, 15(2), (2000), 187-213, DOI 10.1016/S0886-7798(00)00046-8

5 Coulomb $\mathrm{Ca}, \mathrm{Su}$ une application des règles maximis et minimis a quelques problèmes de statique, relatives à l'architecture, Académie des Sciences Paris, Memorial Mathématiques et Physique, 7, (1996), 343-382.

6 De Luque A, Porja T, Martín A, Guijarro JA, Alonso S, A case of severe flood over Albania: a rainfall analysis from a satellite perspective, Advances in Geosciences, 7, (2006), 65-72, DOI 10.5194/adgeo-7-65-2006, 2006

7 Farah K, Ltifi M, Abichou T, Hassis H, Comparison of some probabilistic methods for analyzing slope stability problem, International Journal of Civil Engineering, 1, (2013), 264-268.

8 Hoek E, Marinos P, Benissi M, Applicability of the Geological Strength Index (GSI) classification for very weak and sheared rock masses. The case of the Athens Schist Formation., Bulletin of Engineering Geology and the Environment, 57(2), (1998), 151-160, DOI 10.1007/s100640050031

9 Hoek E, Estimating Mohr-Coulomb friction and cohesion values from the Hoek-Brown failure criterion., In International Journal of Rock Mechanics and Mining Sciences \& Geomechanics Abstracts, 27(3), (1990), 227-229, DOI 10.1016/0148-9062(90)94333-O

10 Kleb B, Geological-technical catastering of areas with surface movement, Periodica Polytechnica Civil Engineering, 32(3-4), (1988), 131-149.

11 Kuka N, Duni L, Aliaj S, Sulstarova E, Seismic Hazard Assessment of Albania by Spatially Smoothed Seismicity Approach, Ohrid, FYROM, s.n., (2003), 78-85.

12 Lamaj M, Kenga M, Rocks fall study and engineering measures of Castel hill slope, Berati town, Albania. Geological Survey of Albania, Tirana, (2010), 528.

13 Muceku Y, Gjoni V, Reçi H, Jata I, Skrami J, Engineering geological zoning mapping of Berati urban area, scale 1:10000, Albania, Albanian Geological Survey, Tirana, (2008), 13-70.

14 Muceku Y, Reshka M, Study of engineering geological condition of landslides occurred in urban Berati area, Albania, Geological Survey of Albania, Tirana, (2005), 5-24.

15 Muceku Y, Korini $\mathbf{O}$, Landslides and slope stability evaluation in the historical town of Kruja, Albania, Journals of Natural Hazards and Earth System Science, Germany, 14, (2014), 545-556, www.nat-hazards-earth-syst-sci.net/14/545/2014// DOI 10.5194/nhess-14-545-2014 Publication type: Journals Natural Hazards Earth System Sciences.
16 Papazachos BC, Savvaidis AS, Papazachos CB, Papaioannou CA, Kiratzi AA, Muco B, Kociu S, Sulstarova E, Atlas of isoseismal maps for shallow earthquakes in Albania and surrounding area (1851-1990), 10(74), (2001), 4-48.

17 Reçi H, Jata I, Skrami J, Electrical Resistance Tomography-(ERT) and seismic investigations for engineering geological zoning mapping of Berati urban area on scale 1:10 000, Albania, Tirana, Geological Survey of Albania, (2008), 3-18.

18 Robertson PK, Soil classification using the cone penetration test, Canadian Geotechnical Journal, 27(1), (1990), 151-158, DOI 10.1139/t90-014

19 Finite Element Analysis for Excavations and Slopes, 2014., https://www. rocscience.com/products/3/RS2\{\%\}20 (Phase2\%20v9).

20 Selenica A, Ardicioglu M, Kuriqi A, Risk assessment from floodings in the rivers of Albania, In: Tirana, International Balkans Conference on Challenges of Civil Engineering, Vol. 1, 2013, pp. 1-8.

21 Sulstarova E, Some historical data about earthquakes of 1851 year in Albania, AJNTS-Journal, 6, (1999), 111-119.

22 Sulstarova E, Some historical data about earthquakes of 1851 year in Albania, AJNTS-Journal, Albanian Sciences Academy, 6, (1999), 111-119.

23 Ván P, Vásárhelyi B, Sensitivity analysis of GSI based mechanical parameters of the rock mass, Periodica Polytechnica Civil Engineering, 58, (2014), DOI 10.3311/PPci.7507

24 Varga G, Czap Z, Soil models: safety factors and settlements, Periodica Polytechnica Civil Engineering, 48(1-2), (2004), 53-63.

25 Vieira CS, A simplified approach to estimate the resultant force for the equilibrium of unstable slopes, International Journal of Civil Engineering, 1, (2014), 65-71. 